\title{
Polsko-włoskie badania nad historiq opieki i wychowania. Stanisław Litak i Gabriele De Rosa
}

\author{
Italian-Polish Research \\ on the History of the Care and Education: \\ Stanisław Litak and Gabriele De Rosa
}

\begin{abstract}
ABSTRAKT
Największy wpływ na moje życie i zainteresowania naukowe dotyczqce historii opieki społecznej i wychowania wywarli profesorowie Stanisław Litak (1932-2010) i Gabriele De Rosa (1917-2009). Prof. Litak zwiqzany był zawsze z Katolickim Uniwersytetem Lubelskim. Był moim nauczycielem i Mistrzem, a zarazem promotorem mojej pracy magisterskiej oraz pracy doktorskiej. Był wybitnym badaczem historii Kościoła, szczególnie parafii. Drugie pole jego zainteresowań stanowiła historia oświaty, szkolnictwa i wychowania. Wyniki swoich badań publikował w ujęciach kartograficzno-atlasowych. Jako znakomity znawca archiwów kościelnych należał do najwybitniejszych specjalistów od kartografii i geografii historycznej.

Moje zainteresowania naukowe inspirował również prof. Gabriele De Rosa. Ten wybitny historyk angażował się również w politykę. Należał do Chrześcijańskiej Demokracji, był posłem do parlamentu włoskiego i senatorem Republiki Włoskiej. Wykładał na uniwersytetach w Salerno, Padwie, Rzymie. Pełnił funkcje dyrektora wielu organizacji, wydawnictw
\end{abstract}

SLOWA KLUCZOWE Stanisław Litak, Gabriele De Rosa, Rzym, Lublin, historia wychowania, historia opieki

KEYWORDS

Stanisław Litak, Gabriele De Rosa, Rome, Lublin, history of education, history of care

SPI Vol. 21, 2018/2

ISSN 2450-5358

e-ISSN 2450-5366 DOI: 10.12775/SPI.2018.2.006

Nadestano: 30.01 .2018

Zaakceptowano: 30.05 .2018

Artykuły i rozprawy 
i czasopism naukowych. Między innymi był dyrektorem Instytutu Luigiego Sturzo (1979-2006), którego byłem stypendysta oraz działajqcej przy nim Szkoły Historycznej Włosko-Polskiej (1983-1996). U niego też odbyłem w 1981 roku staż naukowy na Uniwersytecie Sapienza w Rzymie. Był badaczem włoskich ruchów katolickich, historii Kościoła, miłosierdzia, pobożności ludowej i religijności, zwolennikiem koncepcji francuskiej szkoły Annales.

\section{ABSTRACT}

The biggest influence on my life and science interests regarding history of social care and education had professors Stanisław Litak (19322010) and Gabriele De Rosa (1917-2009). Prof. Litak was always related with Catholic University of Lublin. He was my teacher, master and promoter of my master thesis and $\mathrm{PhD}$ thesis. He was a prominent scientist of the history of the Church, especially parishes. The second field of his interests was the history of learning and education. He published the results of his research by means of atlas-cartographical methods. As the excellent expert Church archives he belonged to the most prominent specialists of cartography and historical cartography.

My science interests were inspired also by professor Gabriele De Rosa. The prominent historian was also engaged in politics. He belonged to Christian Democracy, envoy to the Italian parliament and senator of Italian Republic. He lectured on universities in Salerno, Padova, Rome. He was performing the function of the of lots of organizations, publishing houses and scientific journals. Among others he was a director of Luigi Sturzo Institute (19792006) and operating with it Italian-Polish Historical School (1983-1996), from which I get a scholarship. In 1981 I have also done scientifical training on the University of Sapienza in Rome with him. He was a researcher of Italian Catholic activities, history of the Church, mercy, folk piety and religiosity. Follower of concept of the French school Annales.

Wprawdzie istnieją niezależne od nas uwarunkowania w istotny sposób determinujące nasze przyszłe życie, takie jak zdrowie, wrodzone zdolności, środowisko społeczne czy zamożność rodziców, to jednak rodzimy się mimo wszystko jako niezapełniona - biała karta, na której wpisywana później treść zależy od nas samych, determinacji, pracowitości, ale i obiektywnych czynników, łutu szczęścia czy napotkanych na naszej drodze osób. Te ostatnie mogą mieć zarówno destrukcyjny, jak 
i kreatywny wpływ na życie człowieka, zwłaszcza w młodym wieku, kiedy poszukuje się właściwych wzorców i mądrych rad przy podejmowaniu różnych decyzji. Gdy spotkamy ludzi, którzy odcisnęli wyraziste, pozytywne piętno w naszym życiu, rozwoju osobowym czy pozytywnie pojętej karierze, mówimy o nich jako o autorytetach, wychowawcach, a chyba najtrafniej jako o mistrzach. Zwłaszcza dla młodych adeptów nauki są oni nieocenionym źródłem inspiracji, często prowadzącym do kontynuowania i sukcesji pól badawczych przez siebie wyznaczonych.

Osobiście miałem szczęście spotkać na mojej drodze życiowej wybitnych ludzi, wśród nich wielkich, niepowtarzalnych mistrzów. Było ich kilku, lecz dwóch z nich przez trzydzieści lub więcej lat w sposób nadzwyczajny towarzyszyło mi w życiu zawodowym i osobistym, kształtowało moją formację intelektualną i karierę naukowo-badawczą. Jednym z nich był prof. Stanisław Litak (1932-2010), drugim prof. Gabriele De Rosa (1917-2009). Z nimi związane są początki i wszystkie dalsze etapy mojego rozwoju naukowego, począwszy od magisterium $\mathrm{z}$ historii $\mathrm{w} 1980$ roku po tytuł naukowy profesora. Byli to Mistrzowie ode mnie starsi o jedno lub prawie dwa pokolenia. Darzyliśmy się wielkim, obopólnym szacunkiem i zrozumieniem. Obaj już odeszli. Obecnie, gdy już sam jestem promotorem młodych naukowców, a więc w jakimś sensie tym, kim byli dla mnie opisywani Profesorowie, zawsze, niejako podświadomie, staram się wykorzystywać wzorce i wartości moich zmarłych Mistrzów we współpracy ze studentami, doktorantami i innymi osobami zajmującymi się badaniami naukowymi.

\section{Profesor Stanisław Litak (1932-2010)}

Prof. dr hab. Stanisław Litak urodził się 23 lutego 1932 roku w podkarpackiej wsi Glinik koło Ropczyc, zmarł 23 lutego 2010 roku w Lublinie. Całe jego zawodowe życie związane było z Katolickim Uniwersytetem Lubelskim, na którym po studiach historycznych (1952-1956) przeszedł kolejno wszystkie stopnie kariery naukowo-dydaktycznej: od 1961 roku na stanowisku asystenta, od 1963 - adiunkta, od 1971 - docenta, od 1983 - profesora nadzwyczajnego i od 1992 - profesora zwyczajnego ${ }^{1}$.

1 Profesorowi Stanisławowi Litakowi poświęcono już kilka artykułów: M. Surdacki, Profesor Stanistaw Litak - historyk Kosiciota, wychowania i szkolnictwa, w: Religie - edukacja - kultura. Ksiega pamiatkowa dedykowana Profesorowi 


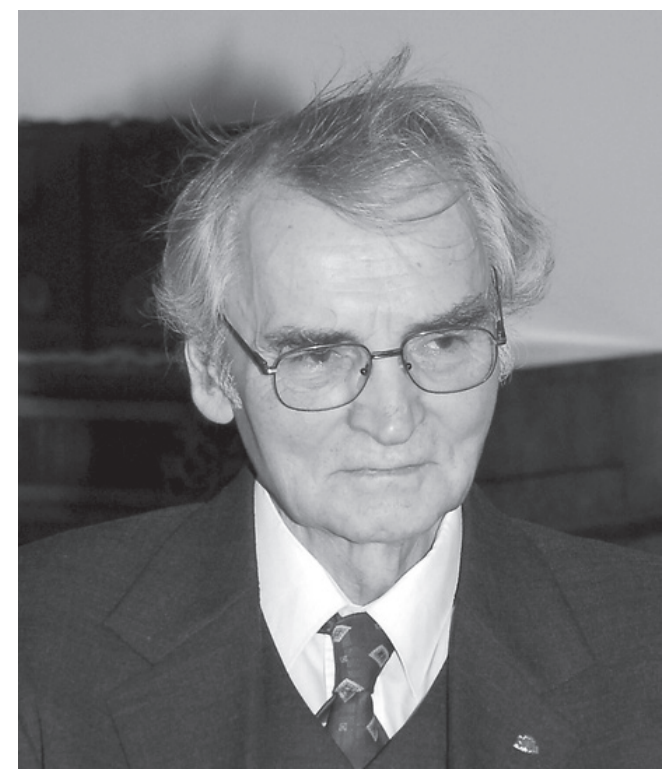

Fot. 1 .

Profesor Stanisław Litak (1932-2010).

Źródło: Archiwum KUL.

$\mathrm{Na}$ drugim roku studiów poznał na ćwiczeniach z historii średniowiecznej doktora Jerzego Kłoczowskiego, który często nawiązywał do problematyki geograficzno-historycznej. Zainspirowany tą tematyką, wybrał jego seminarium, na którym napisał i obronił w 1957 roku pracę magisterską Rozwój sieci parafialnej w archidiakonacie radomskim w średniowieczu.

W listopadzie 1957 roku został zaangażowany w założonym przez Jerzego Kłoczowskiego Instytucie Geografii Historycznej Kościoła w Polsce. Celem Instytutu było opracowanie Atlasu Historycznego Kościoła w Polsce. Praca w Instytucie (do roku 1961) pozwoliła mu

Stanistawowi Litakowi, red. M. Surdacki, Lublin 2002, s. 5-14; M. Surdacki, Profesor Stanistaw Litak, „Przegląd Uniwersytecki” 2002, nr 4(78), s. 24-25; M. Surdacki, Wspomnienie Mistrza i Przyjaciela, w: Vir honestus ac bonus. Stanistaw Litak 1932-2010, red. P. Gach, M. Surdacki, Lublin 2011, s. 139-155; M. Surdacki, Dorobek i warsztat naukowy Profesora Stanistawa Litaka, w: Vir honestus ac bonus. Stanistaw Litak 1932-2010, dz. cyt., s. 215-222; M. Surdacki, Wspomnienia Mistrza i Przyjaciela. Rzecz o Profesorze Stanistawie Litaku, „Głos Ziemi Urzędowskiej” 2012, s. 86-93; M. Surdacki, P. Gach, Od redaktorów, w: Vir honestus ac bonus. Stanistaw Litak 1932-2010, dz. cyt., s. 5-6; J. Szady, Prof. Stanistaw Litak 1932-2010, „Przegląd Uniwersytecki” 2010, nr 2(124), s. 19-20. 
bliżej zapoznać się z problematyką geografii historycznej i parafii. Zainteresowania te później stale pogłębiał.

Doktorat na podstawie pracy Formorwanie sieci parafialnej w $€ u$ kowskiem do końca XVI wieku zrobił i obronił w 1963 roku na UMCS $\mathrm{w}$ Lublinie. Jego formalnym promotorem był prof. Kazimierz Myśliński, choć w praktyce bardziej korzystał z konsultacji naukowych docentów Jerzego Kłoczowskiego i Zygmunta Sułowskiego.

Po doktoracie, w latach 1964-1966, uczestniczył w zespole badań nad strukturami społecznymi, prowadzonym przez prof. Witolda Kulę w Instytucie Historii PAN. Rezultatem jego udziału w tym zespole była rozprawa Duchowieństwo w diecezji lubelskiej w okresie międzyporwstaniowym (1835-1864), opublikowana w 1968 roku w trzecim tomie wydawnictwa pt. Spoteczeństwo Królestwa Polskiego pod red. Witolda Kuli.

W drugiej połowie lat 60. prof. Jerzy Kłoczowski zainicjował zespołowe opracowanie dziejów Kościoła w Polsce. Stanisław Litak podjął się napisania części dotyczącej parafii. Powstała w wyniku tych badań rozprawa Struktura i funkcje parafii w Polsce stała się podstawą kolokwium habilitacyjnego przeprowadzonego na Uniwersytecie Warszawskim w 1970 roku. Została ona opublikowana w tymże roku w pracy zbiorowej pt. Kościót w Polsce, t. II: Wieki XVI-XVIII pod redakcją Jerzego Kłoczowskiego. O tym jak ważnym nurtem zainteresowań była dla Stanisława Litaka parafia świadczy fakt, że jej problematykę podjął kolejno w pracy magisterskiej, doktorskiej i habilitacyjnej. Wraz z geografią historyczną oraz dziejami szkolnictwa i wychowania stała się ona aż do końca życia głównym przedmiotem jego badań i najważniejszych publikacji.

Po napisaniu pracy habilitacyjnej Stanisław Litak podjął się opracowania mapy organizacji Kościoła w Polsce ok. 1772 roku. Praca ta w formie książkowej wraz z osobno drukowanym zestawem map ukazała się w latach 1979 (mapy) i 1980 (książka). Drugie wydanie tej mapy ukazało się w USA w 1990 roku, a trzecie w latach 1991-1992.

Pracę dydaktyczną Stanisław Litak podjął w 1961 roku na Sekcji Historii KUL (dzisiejszy Instytut Historii KUL) jako asystent, następnie jako starszy asystent, po doktoracie jako adiunkt, od 1971 roku pracował na Sekcji Historii KUL jako docent, następnie od 1983 roku już na Sekcji Pedagogiki i równocześnie na Sekcji Historii jako profesor nadzwyczajny, a od 1992 roku jako profesor zwyczajny. 
W 1972 roku objął Katedrę Historii Szkolnictwa i Wychowania na Sekcji Historii (Wydział Nauk Humanistycznych), a od roku 1984 Katedrę Historii Wychowania i Myśli Pedagogicznej na Sekcji Pedagogiki oraz został kuratorem Katedry Historii Szkolnictwa na Sekcji Historii KUL. Natomiast w 2000 roku zrezygnował z pracy w Katedrze Historii Wychowania i Myśli Pedagogicznej na Wydziale Nauk Społecznych i powrócił na Wydział Nauk Humanistycznych KUL, gdzie powierzono mu kierownictwo Katedry Historii Szkolnictwa, nad którą wcześniej sprawował kuratorstwo. Katedra ta przyjęła niebawem nazwę Dydaktyki Historii i Historii Szkolnictwa. Prof. Litak był kierownikiem ww. katedry do czasu swego przejścia na emeryturę w 2005 roku.

Dorobek naukowy Profesora Stanisława Litaka obejmuje około 300 pozycji naukowych. Absolutna ich większość posiada charakter badawczy i oparta jest na kwerendach przeprowadzonych w ponad 100 archiwach i bibliotekach krajowych, a także zagranicznych głównie niemieckich, watykańskich czy litewskich. Więcej niż 30 pozycji opublikowanych zostało w czasopismach i wydawnictwach obcojęzycznych, przede wszystkim niemieckich i francuskich, ale także we włoskich i angielskich.

Bogata i wszechstronna twórczość naukowa Profesora Litaka obejmuje 9 książek o charakterze monograficznym i syntetycznym, ponad 180 artykułów porozrzucanych w czasopismach i pracach zbiorowych (często bardzo obszernych rozpraw), jak też ponad 80 drobniejszych publikacji, przeważnie encyklopedyczno-słownikowych i recenzyjno-informacyjnych. $\mathrm{Na}$ początku aktywności badawczej, w latach 60., zwraca uwagę intensywna współpraca w opracowywaniu Katalogu Zabytkórw Sztuki w Polsce, a także cała seria prezentacji nowości wydawniczych dotyczących zagadnień kościelnych na łamach Revue d'histoire ecclésiatique.

„Klamrą” spinającą całą twórczość naukową Stanisława Litaka jest szeroko pojęta historia Kościoła. Wcześnie wybrana tematyka zainteresowań ukierunkowała rozwijane przez Profesora badania, przede wszystkim na archiwa i materiały kościelne, zwłaszcza akta wizytacji kanonicznych. Propagując i upowszechniając ten typ źródeł, Stanisław Litak dokonał krytycznej edycji unikatowych $A k t W i-$ zytacji Generalnych diecezji Inflanckiej i Kurlandzkiej czyli Piltyńskiej z 1761 roku (1998). 
W dorobku badawczym Profesora fundamentalne miejsce zajmuje tematyka parafialna. Najważniejsza w tym zakresie jest wspomniana już rozprawa habilitacyjna, a zwłaszcza jej mocno uaktualniona i rozszerzona wersja Parafie w Rzeczypospolitej w XVI-XVIII wieku (2004). Niejako przy okazji publikacji opracowań na temat parafii powstały, w początkowym zwłaszcza etapie drogi naukowej, liczne i ważne prace dotyczące miast i osadnictwa.

Badania nad historią Kościoła na ziemiach Rzeczypospolitej w czasach nowożytnych uprawiane przez Stanisława Litaka charakteryzuje ogromna wszechstronność, rzec można, kompletność. Jego badawcza twórczość obejmuje cały szereg opracowań dotyczących duchowieństwa, seminariów duchownych, zakonów, bractw religijnych i kultu religijnego, szpitali, drewnianych monstrancji, budownictwa sakralnego, a także problemów ogólniejszych i dużo szerszych, takich jak: kultura religijna, reformy kościelne, administracyjne struktury Kościoła. Nieobce mu było zainteresowanie zagadnieniem reformacji, mniejszości wyznaniowych i stosunku do nich Kościoła rzymskokatolickiego.

Ogromne doświadczenie i znajomość zasobów kościelnych archiwów zaowocowały powstaniem wspomnianej już mapy, zatytułowanej Struktura terytorialna Kościoła tacińskiego w Polsce w 1772 roku i tomu materiałów będącego jej dokumentacją źródłową. Do dzieła tego nawiązuje monumentalne opracowanie Kościót taciński w Rzeczpospolitej okoto 1772 roku (1996). Obydwa opracowania na stałe weszły do historiografii i stanowić będą, nie tylko przez dziesięciolecia, punkt wyjścia do wszelkiego typu prac kartograficznych i badań nad dziejami Kościoła. Zarazem stanowią one już w tej chwili bezcenne źródło historyczne.

Wyniki tych prac, jak i dokumentacja źródłowa w nich zawarta, znalazły odzwierciedlenie w ujęciach kartograficznych. Opracowanie całej serii map struktur kościelnych stawiają Profesora w rzędzie najwybitniejszych współczesnych specjalistów geografii historycznej i badań kartograficzno-atlasowych. Najważniejszym dziełem, podsumowującym i syntetyzującym badania i publikacje z tego zakresu, a jednocześnie w moim odczuciu najważniejszym dziełem jego życia, jest Atlas Kościota tacińskiego w Rzeczypospolitej Obojga Narodów w XVIII wieku (2006).

Ukoronowaniem i podsumowaniem wysiłków badawczo-pisarskich stały się ujęcia syntezowe dziejów Kościoła w Rzeczpospolitej 
od XVI do końca XVIII wieku. Najważniejszym z nich jest praca Od Reformacji do Oświecenia. Kościót katolicki w Polsce nowożytnej (1994 - 24 mapy),

Niezależnie od problematyki kościelnej, absolutnie dominującej, od początku działalności naukowej Stanisława Litaka drugim polem jego zainteresowań, rozwijanych od połowy lat 70., była historia oświaty, szkolnictwa i wychowania. $\mathrm{W}$ prowadzonych badaniach szczególnie bliskie mu były zagadnienia szkolnictwa parafialnego i zakonnego, Komisji Edukacji Narodowej, a także postać Michała Jerzego Poniatowskiego. Blisko 30 publikacji z tego zakresu daje Profesorowi solidną pozycję wśród polskich historyków oświaty i wychowania. Świadczy o tym dodatkowo liczba rozpraw magisterskich napisanych na ten temat pod jego kierunkiem. Na bazie wykładów stworzył syntetyczne opracowanie - podręcznik akademicki Historia Wychowania, t. 1: Do Wielkiej Rewolucji Francuskiej (2004, 2010²).

Ostatnim dziełem życia prof. Litaka, wydanym już pośmiertnie, jest syntetyczne ujęcie edukacji i szkolnictwa początkowego, głównie parafialnego, w państwie polskim od średniowiecza do reform Komisji Edukacji Narodowej: Edukacja poczatkowa w polskich szkotach w XIII-XVIII wieku (2010).

W 1998 roku Profesor zapoczątkował wydawanie publikacji w serii „Prace z Historii Szkolnictwa w Polsce” (w Towarzystwie Naukowym KUL). Pod jego redakcją wyszło 17 tomów². Na jego życzenie od 2010 roku opiekę nad serią o rozszerzonym nieco tytule („Prace z Historii Szkolnictwa i Opieki Społecznej w Polsce”) przejął piszący te słowa (do chwili obecnej wydano 20 tomów).

Profesor Stanisław Litak należał do różnych historycznych gremiów i towarzystw naukowych. Między innymi był członkiem Polskiego Towarzystwa Historycznego, Commission Internationale d'Histoire Ecclésiastique Comparée, Instytutu Geografii Historycznej Kościoła w Polsce, Towarzystwa Naukowego KUL, Lubelskiego Towarzystwa Naukowego, Komisji Geografii Historycznej w Instytucie Historii PAN, Komisji Porównawczej Kościoła PAN. Brał udział w pracach Komitetu Historycznego PAN, przez kilkanaście lat należał do Rady Naukowej Instytutu Historii Nauki PAN. Był

2 J. Miąso, Prace z historii szkolnictwa w Polsce, „Rozprawy z Dziejów Oświaty” 2005, nr 44, s. 211-216. 
wieloletnim wspólpracownikiem Instytutu Europy Środkowo-Wschodniej ${ }^{3}$. Od połowy lat $90 . \mathrm{z}$ ramienia ministerstwa pełnił rolę recenzenta i opiniodawcy podręczników szkolnych do historii.

Prowadząc badania geograficzno-historyczne dotyczące Kościoła w Polsce, często, począwszy od 1968 roku, wyjeżdżał za granice. Odbył staże naukowe i przeprowadził kwerendy archiwalne i biblioteczne m.in. w: Nijmegen, Londynie, Wiedniu, Leuven, Paryżu, Rzymie, Tybindze, Berlinie, Monachium, Wilnie, Lwowie.

Pod kierunkiem prof. Litaka powstały 124 prace magisterskie, 11 rozpraw doktorskich, był też recenzentem 27 prac doktorskich i 14 rozpraw habilitacyjnych, których autorzy powiększyli grono badaczy historii struktur kościelnych, dziejów osadniczych, opieki społecznej i rozwoju myśli pedagogicznej. Zagadnienia poruszane w pracach magisterskich i doktorskich dotyczyły przede wszystkim problematyki kościelno-religijnej, dziejów parafii, stosunków wyznaniowych zakonów, szkolnictwa i wychowania, kultury i opieki społecznej.

Seminarium doktoranckie prowadzone przez prof. Litaka posiadało zawsze dość niekonwencjonalną, „kolektywną” w dobrym tego słowa znaczeniu specyfikę. W latach 80 . obywało się wspólnie z seminarium doktoranckim prof. Wiesława Müllera. W następnych zaś latach dołączyli do wspólnego seminarium kolejno doktoranci prof. Ryszarda Gapskiego, prof. Janusza Droba i prof. Mariana Surdackiego.

Stanisław Litak bardziej lubował się w swego rodzaju pracy organicznej w badaniach historycznych, w której źródła stanowiły wartość świętą i najważniejszą, niż w uprawianiu tzw. wizji „wielkiej historii”. Uważał, że do syntez, których sam stworzył kilka, należy dochodzić poprzez szczegółowe badania monograficzne. Ich podstawą i punktem wyjścia miały się stać opracowania zjawisk i zagadnień najpierw w skali regionalnej czy mikroregionalnej, potem dopiero w ujęciu ogólnym, globalnym czy porównawczym. Stąd w jego koncepcji historii pojawiały się, realizowane w praktyce, postulaty badań monograficznych nad konkretnymi parafiami, zakonami, bractwami, szkołami, wsiami czy miastami. Sam jestem przykładem praktycznej realizacji jego wizji historii. Twierdził, że nikt inny nie wykona

3 Zob. B. Szady, Stanistaw Litak (1932-2010), „Rocznik Instytutu Europy Środkowo-Wschodniej” 2010, z. 1, s. 192-193. 
za nas tej podstawowej benedyktyńskiej pracy, którą wcześniej doskonale zrealizowali np. badacze niemieccy w trosce o swoją historię regionalną.

Taką strategię postępowania głosił i praktykował, włączając się w rozpoczęty i zainspirowany ponad 50 lat temu przez prof. Jerzego Kłoczowskiego program prac nad stworzeniem Atlasu historycznego Kościota w Polsce, a później Chrześcijaństwa w Europie. Patrząc na bilans dokonań Stanisława Litaka, jego koncepcja „małych kroków” okazała się skuteczna, a prace atlasowe historii Kościoła w osiemnastowiecznej Rzeczpospolitej, które stworzył, stanowią wielki i konkretny wkład do czekającego na finalizację podobnego przedsięwzięcia w szerszym wymiarze geograficznym i chronologicznym.

\section{Profesor Gabriele De Rosa (1917-2009)}

Profesor Gabriele De Rosa. Urodził się 24 czerwca 1917 roku w Castellammare di Stabia (prowincja Neapol), zmarł 20 grudnia 2009 roku. Ukończył studia prawnicze. Brał czynny udział w II wojnie światowej. W randze oficera grenadierów walczył w Afryce Północnej, gdzie brał udział w bitwie pod El Alamein. W czasie okupacji Rzymu przez Niemców, poszukiwany przez SS, przeszedł do podziemnego ruchu oporu. Uczestniczył w nurcie ruchu chrześcijańskiej lewicy. Gdy w grudniu 1945 roku rozwiązano lewicę chrześcijańską, przeszedł do Komunistycznej Partii Włoskiej (PCI), w której obją stanowisko szefa misji i polityki zagranicznej czasopisma „Unità”. W 1952 roku odszedł z tej partii, nie podzielając jej linii światopoglądowej i polityki ideologicznej. Rozczarowany komunizmem, przystąpił do stworzonej przez Luigiego Sturzo Włoskiej Partii Ludowej o charakterze chadeckim. Ruchowi temu został wierny do końca życia.

4 Do opracowania biograficznego fragmentu artykułu, oprócz prac cytowanych w przypisach oraz własnych materiałów i doświadczeń, wykorzystałem dwa rękopisy (Nota Biografica, Gabriele De Rosa) przekazane mi przez Flavię Nardelli, pełniąca przez ponad 20 lat funkcję sekretarza generalnego Instytutu Luigiego Sturzo. Posłużyłem się też publikacjami Profesora De Rosy, które podarował mi w 1981 roku, w czasie rocznego stażu naukowego, jaki odbyłem pod jego kierunkiem na Uniwersytecie La Sapienza w Rzymie. 


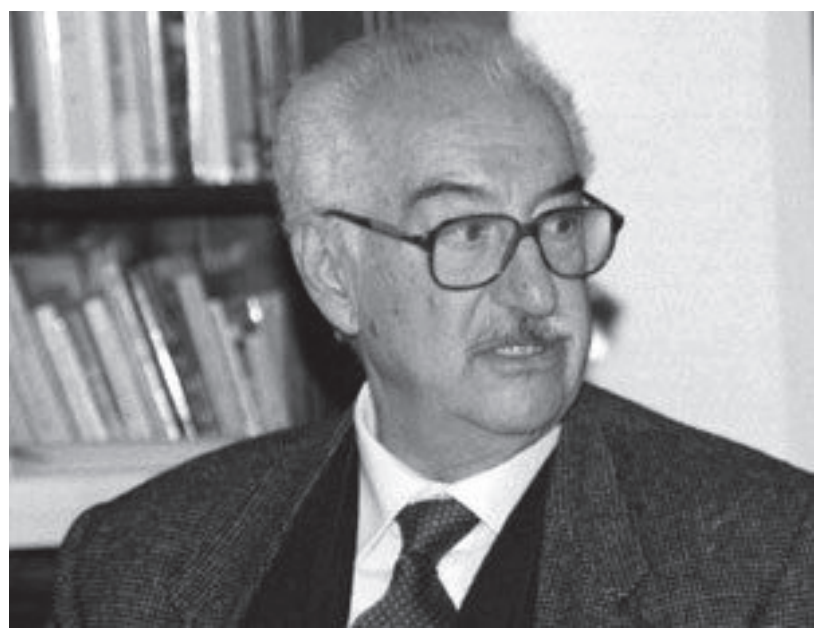

Fot. 2.

Profesor Gabriele De Rosa (1917-2009).

Źródło: Centro Studi „Vincenzo Filippone-Thaulero".

Po wojnie, oprócz aktywności politycznej, De Rosa swoje zainteresowania naukowe zmaterializował poświęcając się studiom historycznym. Przeszedł wszystkie stopnie kariery uniwersyteckiej. Wykładał na uniwersytetach w Salerno - gdzie był pierwszym rektorem (1964-1974), w Padwie oraz w Rzymie (Uniwersytet La Sapienza). W latach 1954-1962 współpracował z wydawnictwem „Edizioni di storia e letteratura", zaś później pełnił w nim funkcję dyrektora naukowego. Przez 20 lat (1951-1971) był redaktorem naczelnym periodyku „Rassegna di politica e storia”. W 1968 roku założył czasopismo „Rivista di studi salernitani”, którym kierował do roku 1971. Kierował też wydawaniem serii rejestrującej źródła historyczne „Thesaurus ecclesiarum Italiae recentioris aevi”.

Był założycielem i kierownikiem wielu instytutów naukowych i centrów studiów, prowadzących badania nad historią Kościoła i życiem religijnym: Centro studi per la storia della Chiesa nel Veneto nell'età contemporanea (Padwa - 1966, od 1975 - Vicenza, pod nazwą Istituto per le ricerche di storia sociale e religiosa). Organem Instytutu było czasopismo: „Ricerche di storia sociale e religiosa”. Od 1994 roku De Rosa był członkiem Centralnej Komisji Studiów Historycznych ( $\mathrm{La}$ Giunta Centrale degli Studi Storici). Był też dyrektorem Associazione per la Storia del Mezzogiorno e dell'Area Mediterranea (Salerno - Potenza). Badania inicjowane i prowadzone w tym ośrodku zapewniły prof. De Rosie europejską pozycję wynikającą z podjęcia pionierskich 
wówczas badań nad najnowszą historią chrześcijaństwa w ujęciu porównawczym ${ }^{5}$. W 1990 roku Instytut w Vicenzie poszerzył obszar swoich zainteresowań historiograficznych na region Europy Środkowo-Wschodniej. W 1991 roku zorganizował w Treviso I Kongres Historyczny „La fede sommersa nei paesi dell'Est”, w którym uczestniczyli historycy i teologowie polscy, litewscy, węgierscy, chorwaccy, francuscy i włoscy ${ }^{6}$. Głównym tematem obrad były przemiany religijne i społeczne w byłych krajach Europy Środkowo-Wschodniej oraz ukazanie wzajemnych relacji między Wschodem a Zachodem na tle sytuacji Kościoła ${ }^{7}$. Od roku 1979 do 2006 był dyrektorem Instytutu Luigiego Sturzo w Rzymie, bardzo ważnej placówki naukowej zbliżonej do środowiska chadecji. Luigi Sturzo (1871-1959) był włoskim duchownym, działaczem społecznym i politykiem katolickim. Swoimi publikacjami i zaangażowaniem politycznym wniósł wielki wkład w demokrację europejską w najbardziej trudnym i burzliwym okresie po II wojnie światowej Niewątpliwie prof. Gabriele De Rosa pozostawał pod dużym wpływem ks. Luigiego Sturzo, którego poznał w 1954 roku.

Profesor był laureatem wielu prestiżowych nagród i wyróżnień. Przykładowo, przez papieża Pawła VI wyróżniony został Orderem Świętego Grzegorza Wielkiego. Był również członkiem Towarzystwa Instytutu Europy Środkowo-Wschodniej w Lublinie. Wcześniej współpracował z Instytutem Europy Środkowo-Wschodniej w Lublinie. W nagrodę za różnorakie zasługi otrzymał też obywatelstwa honorowe wielu miast włoskich.

Intensywną działalność naukową i organizacyjną De Rosa łączył pod koniec XX wieku (przez około 10 lat) z zaangażowaniem politycznym. Przez dwie kadencje był senatorem (1987-1994), przez następne dwie deputowanym parlamentu Republiki Włoskiej. Przewodził grupie senatorów Demokracji Chrześcijańskiej, później Włoskiej Partii Ludowej. Przyjaźnił się z wielokrotnym premierem Włoch Giuliano Andreottim, któremu doradzał.

5 I. Goral,Profesor Gabriele De Rosa ijegootwarciena Europe Srodkowo-Wschodnia, „Rocznik Instytutu Europy Środkowo-Wschodniej” 2007, nr 5, s. 252.

6 La fede „sommersa” nei paesi dell'Est, red. A. Lazzaretto Zanolo, Vicenza 1992 (akta pokonferencyjne, wstęp G. De Rosa).

7 I. Goral,Profesor Gabriele De Rosa ijegootwarciena Europę Środkowo-Wschodniq, dz. cyt., s. 253. 
Gabriele De Rosa ogromną estymą darzył Polskę i Polaków - był ich autentycznym przyjacielem, widział też potrzebę nawiązania kontaktów z naszymi historykami i prowadzenia badań porównawczych w zakresie historii społeczno-religijnej, a dokładniej chrześcijaństwa i jego struktur. Ukoronowaniem nawiązanej współpracy było powołanie, przy kierowanym przez De Rosę Instytucie Luigiego Sturzo, Szkoły Historycznej Włosko-Polskiej w Rzymie (Scuola storica italo-polacca di Roma), działającej w latach 1983-1996. Jej pomysł zrodził w rozmowach profesorów: Jerzego Kłoczowskiego, Gabriele De Rosy i Gerolamo Arnaldiego - dyrektora Istituto storico italiano per il Medioevo. Zadaniem szkoły było promowanie młodych polskich naukowców (historyków, historyków sztuki, archeologów, a nawet socjologów) poprzez fundowanie dwuletnich stypendiów naukowych w Rzymie, finansowanych przez rząd włoski.

Zakończenie działalności szkoły w 1996 roku spowodowane zostało zaprzestaniem jej finansowania przez rząd włoski. Zbiegło się to w czasie z oficjalnym wycofaniem się z polityki Gabriele De Rosy, co ograniczyło możliwość dalszego zdobywania środków na jej działalność. Dla strony włoskiej nie bez znaczenia był fakt, że po odzyskaniu przez Polskę wolności politycznej misja promowania polskich naukowców została po prostu zakończona.

Szkoła Polska w Rzymie stała się dla wszystkich niemal jej uczestników punktem wyjścia do dalszej drogi naukowej. Na bazie zebranych w Rzymie materiałów powstały habilitacje i inne oryginalne prace. Wsparcie materialne ze strony włoskiego rządu wypromowało znanych naukowców i profesorów, którzy pozostawiali swój ślad we włoskiej historiografii, natomiast w Polsce potrafili, w większości przypadków, wykorzystać dany im potencjał w dalszym rozwoju na polu nauki, kultury czy też polityki ${ }^{8}$.

W ostatnich latach życia uprzywilejowany obszar zainteresowań w badaniach Profesora stanowiła Ukraina. Podczas kongresu międzynarodowego „Wielki głód i śmierć na ziemi ukraińskiej 19321933”, odbytego w październiku 2003 roku, obradujący sformułowali i przedstawili w sejmie i senacie wniosek, aby parlament włoski uznał wielki głód na Ukrainie za ludobójstwo.

$8 \quad$ Tamże, s. 254. 
$\mathrm{Na}$ uniwersytetach i w innych środowiskach kulturalno-naukowych, gdzie zawsze odgrywał wiodącą rolę, De Rosa zostawił wyraźny znak swojej obecności i nadzwyczajnej osobowości profesora, naukowca, badacza i organizatora kultury. Swoimi studiami De Rosa wywarł głębokie piętno na historiografii włoskiej XX wieku. Jego badania zorientowane były zasadniczo w kierunku włoskich ruchów katolickich, postaci Luigiego Sturzo, historii Kościoła, miłosierdzia, pobożności ludowej i religijności w nowożytnych i współczesnych Włoszech.

Szczególne znaczenie posiadają jego badania poświęcone włoskiemu ruchowi katolickiemu na szeroko pojętym przełomie XIX i XX wieku. Ich świadectwem jest praca Storia del movimento cattolico in Italia, w której śledzi on kolejno dzieje katolickiej działalności politycznej we Włoszech, od odrodzenia państwa włoskiego do okresu dominacji faszyzmu.

W zakresie tego kierunku badań De Rosa szczególne znaczenie nadał postaci Luigiego Sturzo. W publikacji pt. Luigi Sturzo ukazał sylwetkę kapłana, jego głęboką duchowość i rolę w formowaniu świadomości obywatelskiej i politycznej mas włoskich katolików, poprzez ukazywanie wielkich walorów wolności i demokracji. Z założycielem partii ludowej Profesor prowadził stały, intensywny dialog, co znalazło wyraz w książce pt. Sturzo mi disse.

Oprócz badań i publikacji z zakresu historii politycznej, Profesor koncentrował się szczególnie na tematyce pastoralnej, miłosierdzia, pobożności, świętości i religijności ludowej. Na jego prace duży wpływ wywarł Gabriel Le Bras oraz doświadczenia i koncepcje francuskiej szkoły Annales, bliskiej także piszącemu te słowa. De Rosa prowadził również badania wielkiej wagi i oryginalności, przede wszystkim na temat historii społecznej i religijnej południowych Włoch (Vescovi, popolo e magia nel Sud $)^{9}$.

Olbrzymi wkład wniesiony przez Gabriele De Rosę w badania historyczne polega przede wszystkim na rygorystycznym stosowaniu metody naukowej odznaczającej się nieustannym krytycyzmem, przywiązywaniu wielkiej wagi do dokumentów i kwerend archiwalnych, a zarazem nieustającym zaangażowaniu obywatelskim wyrosłym i kierowanym żywą i głęboką inspiracją moralną i religijną.

9 G. De Rosa, Storie di santi, Roma - Bari 1990, s. IX. 
Profesor pozostawil po sobie ogromną spuściznę naukowo-pisarską i wiele inicjatyw, jak: instytuty, wydawnictwa, i co ważniejsze, wyrazistą formację intelektualno-duchową oraz właściwą sobie ideologię. Jestem przekonany, że tak jak w wypadku Luigiego Sturzo jego życie i działalność stanie się przedmiotem niekończących się studiów $^{10}$.

Profesora Gabriele de Rosę po raz pierwszy spotkałem 8 stycznia 1981 roku w czasie stażu naukowego na Uniwersytecie La Sapienza w Rzymie, który odbywałem pod jego kierunkiem. Tego dnia przyjął mnie w siedzibie Instytutu Luigiego Sturzo. Zrobił na mnie wielkie wrażenie. Był to człowiek dostojny, o manierach arystokraty, fascynował swoją osobowością i postawą ${ }^{11}$.

W czasie spotkania zostałem obdarowany serią naukowych książek z zakresu historii społecznej, wydawanych przez wydawnictwo Edizioni di storia e letteratura, a także egzemplarzami czasopisma „Ricerche di storia sociale e religiosa”. W tym ostatnim sam opublikowałem w późniejszym czasie wiele swoich artykułów. Profesor był wtedy wykładowcą na Uniwersytecie La Sapienza. Zaproponował mi uczestniczenie w prowadzonych przez siebie na Wydziale Nauk Politycznych wykładach i w seminarium, które trwały od stycznia do końca czerwca 1981 roku. Na zajęcia zapraszał swoich współpracowników, m.in. księdza Vincenzo Paglię (obecnie arcybiskupa w kongregacji watykańskiej), wybitnego badacza bractw religijnych i dobroczynności, proboszcza parafii i kościoła Santa Maria in Trastevere, w którym spoczywa kardynał Stanisław Hozjusz. Do dziś utrzymuję z nim ścisłe kontakty naukowe.

Kolejne spotkanie z prof. De Rosą miało miejsce jesienią 1986 roku podczas stypendium na Uniwersytecie dla Cudzoziemców

10 M. Surdacki, Profesor Gabriele De Rosa (1917-2009), „Rocznik Instytutu Europy Środkowo-Wschodniej” 2010, z. 1, s. 65-74.

11 Osobistym refleksjom dotyczącym Prof. Gabriele de Rosy poświęcone są artykuły: M. Surdacki, Il Professore Gabriele De Rosa, come lo ricordo, „Ricerche di storia sociale e religiosa" 2010, nr 78, s. 268-272; M. Surdacki, Polityk, historyk - mój Autorytet - prof. Gabriele De Rosa (1917-2009), w: Źródta wielkości mistrzów. Księga jubileuszowa dedykowana profesorowi Piotrowi Pawtowi Gachowi, red. M. Nowak, R. Jusiak, J. Mazur, Lublin 2013, s. 397415; M. Surdacki, Chociaż odeszli, lecz we mnie sq. Wspomnienie o prof. Gabriele De Rosa, „Głos Ziemi Urzędowskiej”2010, s. 86-90. 
w Perugii ${ }^{12}$. To właśnie wtedy zasugerował mi badania nad największą instytucją charytatywną $\mathrm{w}$ dawnym świecie chrześcijańskim - Szpitalem Świętego Ducha w Rzymie. Badania nad wskazanym tematem (jak się okazało, przyszłą habilitacją) kontynuowałem w czasie stypendium (1988-1990) w ramach Szkoły Historycznej Włosko-Polskiej, której założycielem był właśnie prof. De Rosa.

Po odbyciu dwuletniego stypendium moja oficjalna współpraca z włoskim Mistrzem w zasadzie się zakończyła, jednak nieformalne kontakty trwały nadal. W latach 1991-2000 przeciętnie dwa razy w roku odwiedzałem go przy okazji prywatnych wyjazdów do Rzymu, jak i podczas pobytu na stypendiach Fundacji Lanckorońskich. Rezultatem spotkań było opublikowanie przeze mnie kilkunastu artykułów w czasopismach i wydawnictwach włoskich i jednej książki. Kilka z nich wydrukowano w periodykach kierowanych przez Prof. De Rosę („Studium”, „Ricerche di storia sociale e religiosa”), inne w wydawnictwach przez niego rekomendowanych („Archivio della società romana di storia patria”, ,Dolentium Hominum. Chiesa e Salute nel Mondo”, „Il Veltro. Rivista della civiltà Italiana”, „Medicina nei secoli”). Wszystkie włoskie publikacje były pokłosiem kwerend i badań patronowanych przez Instytut Luigiego Sturzo i prof. Gabriele De Rosę. Powstały na bazie książki habilitacyjnej Dzieci porzucone w Szpitalu Śriętego Ducha w Rzymie w XVIII wieku (1998). Jej promocja odbyła się w Stacji Naukowej PAN w Rzymie 28 kwietnia 1999 roku z udziałem trzech wybitnych historyków włoskich: prof. Girolamo Arnaldiego, dyrektora rzymskiego Instytutu Studiów nad Średniowieczem, prof. Gabriele De Rosy oraz prof. Franesco Malgeriego. Padła wtedy propozycja opublikowania włoskiej wersji monografii, co też nastąpiło w 2002 roku. Książka, do której przedmowę napisał prof. De Rosa, nosi tytuł Il brefotrofio dell'Ospedale di Santo Spirito in Roma nel XVIII secolo.

Profesor Gabriele De Rosa wywarł niezatarte i niepowtarzalne piętno w moim życiu. Ale nie tylko ja tak wiele mu zawdzięczam.

12 Stypendium otrzymałem od Associazione Pier Giorgio Frassati - Amici della Università Cattolica di Lublino dzięki Pani Wandzie Gawrońskiej, która była twórczynią i prezydentem tej fundacji. Zob. M. Surdacki, Wanda Gawronska - Polsce i Katolickiemu Uniwersytetowi Lubelskiemu, „Przegląd Uniwersytecki” 2016, nr 2(160), 39-42. 
W stworzonej przez niego Historycznej Szkole Włosko-Polskiej doświadczenia i szlify naukowe zdobyło około 20 młodych polskich badaczy.

\section{Bibliografıa}

De Rosa G., Storie di santi, Laterza, Roma - Bari 1990.

Goral I., Profesor Gabriele De Rosa i jego otwarcie na Europe Środkowo-Wschodnia, „Rocznik Instytutu Europy Środkowo-Wschodniej” 2007, nr 5, s. 251-256.

La fede "sommersa” nei paesi dell'Est, red. A. Lazzaretto Zanolo, Neri Pozza Editore, Vicenza 1992 (akta pokonferencyjne, wstęp G. Dr Rosa).

Miąso J., Prace z historii szkolnictwa w Polsce, „Rozprawy z Dziejów Oświaty” 2005, nr 44, s. 211-216.

Surdacki M., Dorobek i warsztat naukowy Profesora Stanistawa Litaka, w: Vir honestus ac bonus. Stanistaw Litak 1932-2010, red. P. Gach, M. Surdacki, Towarzystwo Naukowe KUL, Lublin 2011, s. 215-222.

Surdacki M., Chociaż odeszli, lecz we mnie sa. Wspomnienie o prof. Gabriele De Rosa, „Głos Ziemi Urzędowskiej” 2010, s. 86-90.

Surdacki M., Polityk, historyk - mój Autorytet - prof. Gabriele De Rosa (19172009), w: Źródta wielkości mistrzów. Ksiegga jubileuszowa dedykowana profesorowi Piotrowi Pawtowi Gachowi, red. M. Nowak, R. Jusiak, J. Mazur, Wydawnictwo KUL, Lublin 2013, s. 397-415.

Surdacki M., Il Professore Gabriele De Rosa, come lo ricordo, „Ricerche di storia sociale e religiosa" $2010, \mathrm{nr} 78$, s. 268-272.

Surdacki M., Profesor Gabriele De Rosa (1917-2009), „Rocznik Instytutu Europy Środkowo-Wschodniej" 2010, z. 1, s. 65-74.

Surdacki M., Profesor Stanistaw Litak - bistoryk Kościoła, wychowania i szkolnictwa, w: Religie - edukacja - kultura. Ksiega pamiqtkowa dedykowana Profesorowi Stanistawowi Litakowi, red. M. Surdacki, Towarzystwo Naukowe KUL, Lublin 2002, s. 5-14.

Surdacki M., Profesor Stanistaw Litak, „Przegląd Uniwersytecki” 2002, nr 4(78), s. 24-25.

Surdacki M, Wanda Gawrońska - Polsce i Katolickiemu Uniwersytetowi Lubelskiemu, „Przegląd Uniwersytecki” 2016, nr 2(160), s. 39-42.

Surdacki M., Wspomnienie Mistrza i Przyjaciela, w: Vir honestus ac bonus. Stanistaw Litak 1932-2010, red. P. Gach, M. Surdacki, Towarzystwo Naukowe KUL, Lublin 2011, s. 139-155.

Surdacki M., Wspomnienia Mistrza i Przyjaciela. Rzecz o Profesorze Stanistawie Litaku, „Głos Ziemi Urzędowskiej” 2012s. 86-93.

Surdacki M., P. Gach, Od redaktorów, w: Vir honestus ac bonus. Stanistaw Litak 1932-2010, red. P. Gach, M. Surdacki, Towarzystwo Naukowe KUL, Lublin 2011, s. 5-6. 
Szady B., Stanistaw Litak (1932-2010), „Rocznik Instytutu Europy Środkowo-Wschodniej” 2010, z. 1, s. 192-193.

Szady J., Prof. Stanistaw Litak 1932-2010, „Przegląd Uniwersytecki” 2010, nr 2(124), s. 19-20.

\section{ADRES DO KORESPONDENCJI:}

Prof. dr hab. Marian Surdacki

Katolicki Uniwersytet Lubelski Jana Pawła II

Instytut Pedagogiki

e-mail: msurd@kul.lublin.pl 